\title{
Enhancing environmental sustainability through corporate governance: the merger and acquisition perspective
}

\author{
Dandan Zheng ${ }^{1,2}$, Zhipan Yuan ${ }^{3}$, Shusheng Ding ${ }^{1 *}$ (D) and Tianxiang Cui ${ }^{4^{*}}$
}

\begin{abstract}
Background: Environmental sustainability may be perceived as conflicting with economic development. Economic activities such as mergers and acquisitions can contribute to resource allocation optimization, where corporate governance plays an important role in advancing environmental sustainability. Our study broadens the investigation of whether mergers and acquisitions are helpful for sustainable environmental development. We attempt to reveal the mechanism by which mergers and acquisitions affect sustainable development: namely, through corporate governance.

Results: By employing panel data for Chinese listed companies, we reveal that mergers and acquisitions have a significant positive influence on environmental sustainability. In particular, the study documents a mediating effect of corporate governance. We argue that mergers and acquisitions can trigger company reorganizations and thus optimize firm structure, resulting in better corporate governance. This effect, in turn, can enhance company management in several aspects, including sustainable environmental development. Therefore, we conclude that the government can improve corporate governance by promoting board reorganizations via mergers and acquisitions, leading to better environmental sustainability.
\end{abstract}

Conclusions: This paper can inspire future research avenues by shedding light on how economic development and environment sustainability can be harmonized through better corporate governance. It can also deliver research implications on corporate governance studies through mergers and acquisitions.

Keywords: Mergers and acquisitions, Environment sustainability, Probit model, Corporate governance, Mediating effect

\section{Background}

Decades of environmental policies have been dedicated to enhancing environmental sustainability by means of achieving carbon neutrality or energy usage efficiency, for example. Nevertheless, there may always

*Correspondence: dingshusheng@nbu.edu.cn; tianxiang.cui@nottingham. edu.cn

${ }^{1}$ The School of Business, Ningbo University, Ningbo, China

${ }^{4}$ School of Computer Science, University of Nottingham Ningbo China, Ningbo, China

Full list of author information is available at the end of the article be a conflict between economic activities and environmental sustainability. According to triple bottom line theory [1], economic, environmental and social value should be harmonized to achieve sustainable development [2]. This view proposes a new evaluation system for measuring the success of an organization or society overall regarding enterprise behavior in three aspects: economic, ecological and social context. In addition, Katherine and Thompson [3] demonstrate that mergers and acquisition (M\&A) activity is an important economic activity that has a crucial impact on enterprise success both economically and socially. To evaluate original author(s) and the source, provide a link to the Creative Commons licence, and indicate if changes were made. The images or other third party material in this article are included in the article's Creative Commons licence, unless indicated otherwise in a credit line to the material. If material is not included in the article's Creative Commons licence and your intended use is not permitted by statutory regulation or exceeds the permitted use, you will need to obtain permission directly from the copyright holder. To view a copy of this licence, visit http://creativecommons.org/licenses/by/4.0/. The Creative Commons Public Domain Dedication waiver (http://creativeco mmons.org/publicdomain/zero/1.0/) applies to the data made available in this article, unless otherwise stated in a credit line to the data. 
M\&A deals from the social and environmental perspectives, we should consider not only whether they maximize shareholder value in terms of short-term financial objectives but also-from the perspective of sustainable development of enterprises-whether they fulfill their social responsibilities and optimize the triple bottom line components of economic, social and environmental welfare [4].

However, conflicting interests exist among economic, social and environmental objectives. As a result, it would be difficult for an enterprise to harmonize all three aspects of welfare when no overarching optimization criterion is available. Furthermore, environment protection has been emphasized by Chinese government recently. The Chinese government has put heavy attention on achieving the carbon neutrality target now $[5,6]$. Therefore, we choose firms within manufacturing and mining industries as sample, which are high pollution industries and they are more concerned about the environment protection.

Notably, scholars suggest that M\&As can be perceived as a way for firms to achieve a balance among economic, environmental and social value for themselves. Goerner et al's [7] study examines the relationship between the economic activities of enterprises and the global environment to enhance and reliably maintain the health and well-being of all levels of global civilization as well as the planet. The mechanism by which M\&As can improve the effectiveness of environmental protection can be described as follows. To achieve synergies, the acquirer integrates with the target firm. If the velocity and intensity of integration are maximized, then the acquirer can optimize resource allocation and improve the utilization rate of resources $[8,9]$.

Making changes to corporate governance structures is one of the major objectives of M\&As [10]. According to triple bottom line theory, under a sound corporate governance framework, corporate behavior should consider economic, social and environmental perspectives. Only under the premise of not eroding stakeholders' interests can shareholders' rights and interests be maximized [11]. Moreover, corporate governance is often underpinned by agency theory, which defines a successful corporate governance as maximizing the firm value [12]. This argument is often considered as ignoring the legitimate claimants, such as the society and the environment [13]. As a result, we identify the theory gap between different layers of the agencies. Out study further demonstrates that the sound corporate governance not only aims at maximizing the firm value for the shareholder but also be effective in protecting the interest of the society and environment. Filling this gap provides decent connections between triple bottom line theory and agency theory.
The effect of M\&As on corporate governance has been substantially investigated in the literature [14], but the impact of M\&As on sustainable development remains insufficiently understood. As a result, we aim to explore two research questions in this paper. First, can M\&As in heavily polluting industries, namely, the manufacturing and mining industries, be helpful for sustainable development? If so, is this improved sustainability achieved through better corporate governance via M\&As? To scrutinize the impact of M\&As on sustainable environmental development, we examine the impact of M\&As in regards to four aspects: firm environmental performance, firm environmental cost, corporate social responsibility and green credit. On the basis, we employ five proxies of environmental protection as dependent variables in this study. In particular, we have three direct measures of environmental protection, which are environmental performance, measured by whether the enterprise discharges a key pollutant, corporate social responsibility, measured by whether there is an independent corporate social responsibility report and green finance, measured by total energy consumption. The other two measures are indirect measures of environmental protection, namely, environmental cost, measured by long-term accounts payable and research and development, measured by total research and development expenditure.

First, environmental performance relates to efforts to reduce adverse impacts on the external environment. It is evident that M\&As have a significant impact on financial performance, for instance, return on net assets, which may engender an indirect impact on environmental performance [15].

Environmental cost refers to the cost of a decline in ecosystem services due to environmental pollution caused by economic activities. It is the total cost required to address environmental pollution and ecological damage from resource exploitation, production, transportation and so on [16].

The corporate social responsibility evaluation system is divided into economic, social, environmental, legal, charitable and other responsibilities [17]. Zhang et al. [18] construct a theoretical framework of corporate social responsibility based on the perspective of stakeholders. They find that the concerns of stakeholders have shifted from being exclusively about financial information, such as profitability to encompassing corporate social responsibility performance and the quality of information disclosure. With the increasingly competitive capital market, social reputation can enhance firm influence and competitiveness through potential market channels [19]. Moreover, Deng et al. [20] examine the relationship between corporate social responsibility (CSR) and M\&As using a large sample of mergers in US. They conclude 
that acquirers' social performance is an important determinant of merger performance.

To achieve better CSR performance, the firms would be more active in environmental protection. Peng et al. [21] conclude that M\&A and R\&D improve the firm's environmental activities which is also associated with CSR. Peng et al. [22] also study how corporate social responsibility (CSR) impacts M\&A decisions and firm's development by applying bootstrap-based conditional logit models. They clearly points out CSR promotes a long-term perspective on value-creation, facilitates integration across organizations and the innovation of the firm, which are all benefit for environmental improvement.

The green credit system structures the relationship between the financial industry and sustainable development. In credit activities, compliance with environmental standards, pollution control and ecological protection are taken as prerequisites for credit approval, and funds are directed toward industries and enterprises that are responsible for environmental protection to realize sustainable development [23]. "Green Credit" refers to the preferential policies that financial institutions give to projects with sustainable development that meet the requirements of environmental protection [24]. Green banking is generally defined as banking operation activities aiming at reducing customers' carbon footprint by promoting environmentally friendly practices [25]. Both green credit and green banking are environment-friendly, while in green banking, managers and officers are resourceful emphasizes on recycling of left-over materials, keeping the environment pollution free, and performs to reduce resource wastages [26]. Since green credit focuses primarily on financial instruments to enhance the level of environmental protection.

Based on the empirical analysis, our paper makes the following contributions to the existing literature. First, we scrutinize the impact of M\&As on environmental sustainability in heavy pollution industries in China. We complement previous studies by showing that M\&As can enhance environmental sustainability through a synergistic effect and better corporate governance. More importantly, we demonstrate the mediating effect of corporate governance in the nexus between M\&As and environmental sustainability in heavy-pollution industries. We reveal that the mediating effect of corporate governance is more pronounced in the mining industry than in the manufacturing industry. Finally, we undertake a robustness check by replacing the M\&A dummy variable with the M\&A economic value added rate. On this basis, we further examine the mediating effect of corporate governance in the manufacturing industry. Our results reveal that corporate governance plays an intermediate role in connecting M\&As with environmental sustainability. It is plausible that M\&As trigger company reorganizations and thus help optimize firm structure, resulting in better corporate governance, improving company management in terms of sustainable environmental development.

This paper is organized as follows: "Literature review and proposed hypotheses" section develops the hypotheses; "Method and data" section addresses sample construction and relevant data; "Empirical results and discussion" section presents the empirical results; and "Conclusions and research implications" section concludes the paper.

\section{Literature review and proposed hypotheses}

M\&As, which refer to a transfer of rights based on institutional arrangements for corporate control rights, are a highly studied topic in finance. Existing scholars examine the role of M\&As and emphasize that their effect is highly correlated with the M\&A motivations [27]. Yoo et al. [28] demonstrate that M\&As have a large effect on enterprise value, specifically for renewable companies, which are considered to offer potential investment products. Yuan and Dai [29] argue that M\&As put firms in a better position to fulfill environmental and social responsibilities. The effect of M\&A on the environment sustainability is documented not only in Chinese context, but also can be found worldwide. For instance, Kim et al. [30] take several typical countries in Asia, containing India and Indonesia, as research sample. Their research highlights that mergers and acquisition stimulates the corporations to get more green patent applications, which makes the firm to be more environmental friendly. Similarly, Stefano et al. [31] indicate that the long-term effects of an M\&A operation are positively connected to performance in terms of corporate sustainability by examining all completed M\&A deals between 2000 and 2019 in US.

More importantly, numerous scholars have demonstrated that M\&A is vital important to the shareholders' protection from various aspects. Ahiabo et al. [32] prove that cross-border mergers and acquisitions have brought significantly wealth effect to their shareholders by enhancing the corporate governance. They verify that cross-border mergers and acquisitions are mainly influence shareholders' protection through absorbing efficient legal system. In addition, Dandapani et al. [33] adopt US data from January 1980 to June 2016 and investigate the wealth effects of the strategic decision of a firm to become a multinational firm. In addition, they provide robust evidence that M\&A realize positive abnormal return which attaches a significant premium for the shareholders through the corporate governance.

Since M\&As bring a scale effect, they can improve corporate performance, such as stock market yield and return on equity [34], by optimizing resource allocation, 
sharing, and utilization [35]. In addition to the improvement of the above traditional financial indicators, scholars have begun to pay attention to nontraditional performance metrics, such as environmental performance. In the context of globalization and industrial chains, the environmental performance of M\&As refers to environmental management measures that express the actual environmental consequences related to M\&As. Thus, environmental performance is a sound criterion for evaluating the results of M\&As. M\&As can help companies gradually reorient the entire industrial chain toward environmental protection to reduce environmental pollution [36].

According to $\mathrm{Yu}$ and Wang [37], the indicator system for environmental performance evaluation can be divided into 6 first-level indicators and 32 second-level indicators, with the former including environmental compliance, environmental operation performance, environmental management performance, environmental control efficiency, environmental protection expenditure, and external communication performance. In this context, we offer the following hypothesis:

Hypothesis 1. Companies can achieve better environmental performance through M\&As.

Stakeholder theory posits that stakeholders inject necessary M\&A resources into enterprises. Zhou [38] contends that corporations pay more attention to achieving the optimal allocation of resources after M\&As. A large amount of M\&A activity has emerged, creating scale effects and thus helping optimize resource allocations and lower costs, including environmental costs. Environmental cost refers to the cost of ecosystem service quality degradation due to environmental pollution caused by economic activities. This indicator comprises all expenses incurred from environmental pollution and ecological destruction through, for example, resource extraction, production, and transportation [39]. Specifically, strategic control of corporate environmental costs plays an important role in incentivizing the establishment of an economic development model for companies to achieve win-win economic and environmental outcomes [40]. M\&As can shift this cost curve, substantially lowering fixed costs and thus motivating firms to undertake greenfield investments that reduce firm environmental costs [41].

The existing literature on environmental costs mainly focuses on various traditional financial indicators, such as pollution charges in operating costs and long-term prepaid expenses [42]. However, scholars have begun to pay attention to the cost of various stages of environmental pollution. This includes costs incurred before, during and after an activity, not just at the stage when pollution occurs. Thus, we posit the following hypothesis:

Hypothesis 2. Companies can achieve lower environmental costs through M\&As.

In the process of M\&A expansion, companies with better social responsibility performance can obtain richer resources from stakeholders, unlocking the M\&A wealth effect and creating excess profits to give rise to the conditions for the assumption of corporate responsibility for the environment [43]. Firms can be restructured to optimize their configuration, reduce pollution incidents and improve the natural environment through M\&As [44]. Meanwhile, M\&As can improve the reputation of enterprises with the public and regulators. As a result, these firms may also take on more social responsibilities and may be subject to less supervision from relevant departments or even lower investment risk in a foreign country [45].

Companies engaged in M\&As, especially state-owned enterprises, are more likely to consider social responsibilities, such as environmental protection, beyond their interest in economic benefits [46]. Moreover, scholars find that pollution reductions from M\&As can improve resource utilization efficiency, reduce waste and increase profitability, which also improves environmental performance [47]. Most articles evaluate the performance of companies after M\&As from the perspective of economic and social indicators. They adopt variables such as cumulative average abnormal returns, buy-and-hold abnormal returns, social responsibility rating data, and some key financial data to test whether environmental performance improves when companies participate in M\&As. In this context, we offer the following hypothesis:

Hypothesis 3. Companies participating in M\&As are more willing to devote themselves to corporate social responsibilities, such as environmental protection, thereby improving environmental performance.

Financing is a ubiquitous concern for most corporations, especially heavily polluting firms, such as those in the coal and steel industries. Credit constraints make it difficult for firms to obtain loans from banks [48]. Since 2007, China has implemented a green credit policy, which encourages banks to end financing for polluting industries [49] but encourages borrowers to commit to making green investments and achieving sustainable development [50]. This policy has proven effective in restricting bank lending to energy-intensive and highly polluting projects in China [51]. Nevertheless, green credit financing (GCF) offers these industries a new financing path 
and effectively alleviates financing difficulties [52]. GCF is a financial service provided by banks to encourage borrowers to make green investments and achieve sustainable development [50]. Xue and Zhu [53] claim that it is an effective way to alleviate financing constraints. To obtain GCF, enterprises need to reach a threshold of environmental protection [54]. GCF also has a significant positive effect on the optimization of China's industrial structure [55]. M\&As are a practical means for corporations to obtain GCF from banks [56]. Thus, M\&As are helpful for corporations to secure green financing and improve their environmental protection.

Researchers mainly apply a particular set of indicators to measure green financing development, since green financing is subject to both general financial risks and specific financial risks in operation and management. These indicators include total deposits and loans from financial institutions, energy savings and emission reduction, financial loan structure and total energy consumption [55]. In this context, we offer the following hypothesis:

Hypothesis 4. M\&As can help firms obtain green credit, that is, financing devoted to protecting the environment.

Since we are investigating the environmental performance achieved by M\&As, proper performance indicators are essential. Existing research methods used to evaluate M\&A performance include event studies, financial or accounting indexes, case studies and management investigations, among which the former two are the mainstream methods for studying the post-merger performance of companies in international academic circles [57]. However, a growing number of scholars have realized that purely economic or financial indicators cannot adequately evaluate the performance of M\&As. M\&As are transactions, whereby firms secure advanced technology, talent and resources and enter new industries under the market mechanism [58]. Smith [59] argued that the division of labor and specialization improves labor production efficiency and promotes the expansion of enterprise production scale and that scale economies promote the growth of enterprises. Therefore, M\&As help improve the economic performance of enterprises and achieve sustainable development. The environmental protection effect of M\&As, in turn, can be analyzed in regards to three aspects: motivation, process and economic performance of M\&As [60]. There are three possible types of effects: positive effects, negative effects and zero effects [61]. According to M\&A efficiency theory, since firms differ in their efficiency, they can improve their efficiency through synergies and improve efficiency overall; this prediction has been well verified for the natural resources industry [62, 63]. Since the 1990s, theories of technology spillovers and diversified M\&As based on core capabilities have been widely used in practical research $[64,65]$. However, the system for evaluating the comprehensive performance of green mergers and acquisitions is not perfect [66].

\section{Method and data}

Our paper employs company-year panel data on Chinese firms in two industries (manufacturing and mining) listed on the Shanghai and Shenzhen stock exchanges from 2005 to 2019 and specializing in environmental sustainability. We use a large sample and a long period of time to ensure reliability and to reduce measurement error. We exclude companies that received special treatment or have incomplete data or extreme values. Regarding key variables, we use a number of dummy variables for the data analysis, where the probit model is appropriate.

\section{Data collection and variable definitions}

For the data analysis, we utilize listed Chinese companies in manufacturing and mining industries to illustrate the effect of M\&As on China's environment, as these two industries have a significant impact on the environment and account for a high proportion of GDP. Among the variables, 'MA' represents an M\&A deal; it takes a value of 1 when there is a deal and afterwards and 0 otherwise. 'EVAR' stands for the economic value-added rate. 'GR' stands for the growth rate, which is measured by capacity development. 'NP' is net profit. 'BTMR' represents the book-to-market ratio, which is measured by the relative value index. 'CEDR' is the discount rate, which is measured by the capital expenditure and depreciation and amortization ratio. 'CG' stands for corporate governance, which is measured by the number of board meetings. 'EP' denotes environmental performance, which is measured by whether the enterprise discharges a key pollutant. 'EC' is the environmental cost, which is measured by long-term accounts payable. 'CSR' is corporate social responsibility, which is measured by whether there is an independent corporate social responsibility report. 'GF' denotes green finance, measured by total energy consumption. 'RD' is research and development, measured by total research and development expenditure. The data provider is WIND, and the data period is from 1 Jan 2005 to 31 Dec 2019, which is the period that maximizes data availability across variables, and all data are at annual frequency. Variables and definitions are presented in Table 1.

The panel data sets include four dependent variables (EP, EC, CSR and GF) and two independent variables (MA and EVAR), where MA is the main explanatory variable and EVAR is the alternative explanatory variable for 
Table 1 Variables and measures

\begin{tabular}{|c|c|c|c|}
\hline Category & Variable & Symbol & Formula \\
\hline \multirow[t]{2}{*}{ Independent variables } & M\&A information & MA & 1 in the case of an $M \& A, 0$ otherwise \\
\hline & Economic value added rate & EVAR & $\begin{array}{l}\text { EVAR (Economic Value Added Rate)=Economic Value } \\
\text { Added/Invested Capital=(Net Profit-Cost of Capital)/ } \\
\text { Invested Capital }\end{array}$ \\
\hline \multirow[t]{4}{*}{ Control variables } & Capacity development & GR & Growth Rate of Operating Revenue \\
\hline & Profit & NP & Net Profit \\
\hline & Relative value index & BTMR & Book-to-market Ratio \\
\hline & Discount rate & CEDR & Capital Expenditure and Depreciation and Amortization Ratio \\
\hline Mediator & Number of board meetings & CG & \\
\hline \multirow[t]{5}{*}{ Dependent variables } & Whether the enterprise discharges a key pollutant & EP & 1 if yes, 0 otherwise \\
\hline & Long-term accounts payable & EC & \\
\hline & $\begin{array}{l}\text { Whether there is an independent corporate social } \\
\text { responsibility report }\end{array}$ & CSR & 1 if yes, 0 otherwise \\
\hline & Total energy consumption & GF & \\
\hline & Research and development expenditure & $\mathrm{RD}$ & \\
\hline
\end{tabular}

Table 2 Descriptive statistics of manufacturing industry

\begin{tabular}{lcllll}
\hline Variable & Obs & Mean & Std Dev & Min & Max \\
\hline EVAR & 4471 & 10.417 & 365.614 & -4.075 & $24,293.118$ \\
GR & 19,447 & 0.456 & 15.574 & -0.999 & 1924.53 \\
NP & 21,521 & $2.980 \mathrm{e}+08$ & $1.483 \mathrm{e}+09$ & $-1.867 \mathrm{e}+10$ & $4.840 \mathrm{e}+10$ \\
BTMR & 20,384 & 0.612 & 0.242 & 0.008 & 6.546 \\
CEDR & 21,131 & 3.108 & 21.057 & -3.989 & 2665.048 \\
CG & 1806 & 10.289 & 4.545 & 2 & 44 \\
EP & 2068 & 0.483 & 0.5 & 0 & 1 \\
EC & 9803 & $1.435 \mathrm{e}+08$ & $5.253 \mathrm{e}+08$ & $-6.807 \mathrm{e}+09$ & $1.002 \mathrm{e}+10$ \\
\hline
\end{tabular}

robustness purposes. Since the variables GR, NP, BTRM and CEDR impact sustainable environmental development, we use them as control variables. Meanwhile, we adopt CG (proxied by the number of board meetings) as a mediator to illustrate how the independent variables affect the dependent variables. Corporate governance refers to the rules by which a company is driven and controlled [67]. The frequency of board meetings can serve as a crucial measure of corporate boards' monitoring power and effectiveness [68]. It has been arguable that if the board increases the frequency of board meetings, the recovery from poor performance is faster [69]. As a result, we use the frequency of board meetings to measure corporate governance, where higher meeting frequency indicates firms with strong corporate governance. Descriptive statistics of the manufacturing and mining industries are reported in Tables 2 and 3, respectively.

In Table 3, the total energy consumption data of the manufacturing industry are missing, which makes it impossible to establish subsequent related models. In
Table 3 Descriptive statistics of mining industry

\begin{tabular}{llllll}
\hline Variable & Obs & Mean & Std Dev & Min & Max \\
\hline EVAR & 1248 & 1.069 & 8.684 & -1 & 174.639 \\
GR & 1247 & 0.389 & 2.915 & -1 & 56.174 \\
NP & 1248 & $2.731 e+09$ & $1.373 e+10$ & $-1.611 \mathrm{e}+10$ & $1.507 \mathrm{e}+11$ \\
BTMR & 1247 & 0.506 & 0.375 & 0 & 1.361 \\
CEDR & 1248 & 3.994 & 75.74 & 0 & 2665.048 \\
CG & 1250 & 1.228 & 3.763 & 0 & 37 \\
EP & 1250 & 0.085 & 0.279 & 0 & 1 \\
EC & 1248 & $2.496 e+08$ & $6.992 \mathrm{e}+08$ & 0 & $5.505 \mathrm{e}+09$ \\
GF & 1248 & $27,503,656$ & $8.738 \mathrm{e}+08$ & 0 & $3.074 \mathrm{e}+10$ \\
\hline
\end{tabular}

addition, the volatilities of EVAR and CEDR are large, and the difference between the minimum and maximum is large, while other variables exhibit smaller volatility.

\section{Method}

An examination of a large cross section of observations suggests that panel data are better suited for studying the dynamics of change. From an econometric perspective, panel data can provide more degrees of freedom, information, variation, and less collinearity and allow for individual unobserved heterogeneity [70]. Thus, we use panel data for this investigation. Panel data sets can be of two types: time series and cross-sectional series. Based on the Shenzhen and Shanghai stock exchanges' industry classification, we extract the relevant enterprise data for the manufacturing and mining industries for analysis. We employ the company-year series. All data are arranged according to time and company code, and companies with extreme values and missing data are excluded. 
Since we have dummy variables for some dependent variables, we apply the probit model for these data analyses. The probit model is a multiple probability ratio regression model. It is a discrete choice model, a model type often used to fit a binary dependent variable regression, where the residual items of the probit model follow a standard normal distribution. Its advantages lie in its simple form and easy handling [71].

The general multiple linear regression model equation is as follows:

$$
\mathrm{Y}=\beta_{0}+\sum_{\mathrm{i}=1}^{\mathrm{n}} \beta_{\mathrm{i}} \mathrm{x}_{\mathrm{i}}+\varepsilon_{\mathrm{i}}
$$

where $Y$ is the dependent variable, $x_{i}$ is the $i^{\text {th }}$ explanatory variable and $\varepsilon_{i}$ is the residual term.

To investigate the relationship between the probability $P=P\{Y=1\}$ of the occurrence of M\&As improving environmental performance and each explanatory variable, the probit probability function is used to transform the original equation. Let $\phi(x)$ be the standard normal distribution function; then

$$
\phi^{-1}(P)=\phi^{-1}(P\{Y=1\})=\beta_{0}+\sum_{i=1}^{n} \beta_{i} x_{i}+\varepsilon_{i},
$$

where $P$ is the probability function, $x_{i}$ is the $i^{\text {th }}$ explanatory variable and $\varepsilon_{i}$ is the residual term.

This paper employs panel data models to conduct multivariable regressions. From the proposed hypotheses, we have the following mathematical equations:

$$
\mathrm{Y}(\mathrm{P}\{\mathrm{Y}=1\})=\beta_{\mathrm{i}}^{\mathrm{t}}+\sum_{\mathrm{t}=1}^{\mathrm{n}} \beta_{\mathrm{i}}^{\mathrm{t}} \mathrm{x}_{\mathrm{i}}^{\mathrm{t}}+\varepsilon_{\mathrm{i}},
$$

where $P$ is the probability of M\&As impacting environmental sustainability and $P=1$ represents the occurrence of mergers and acquisitions that promote environmental sustainability. $x_{i}^{t}$ is the $i$ th explanatory variable at time $t$, and $\varepsilon_{i}$ is the residual term.

We implement the probit model for two dependent variable regressions. The first variable is environmental performance, which takes the value of 1 if the enterprise discharges a key pollutant in the associated year and 0 otherwise. The second-dependent variable regression is for corporate social responsibility, which takes the value of 1 if the company has an independent corporate social responsibility report in the associated year and 0 otherwise.
Table 4 Probit results for manufacturing industry

\begin{tabular}{lll}
\hline Variables & $\begin{array}{l}\text { Model 1 } \\
\text { EP }\end{array}$ & $\begin{array}{l}\text { Model 2 } \\
\text { CSR }\end{array}$ \\
\hline GR & -0.00464 & 0.00171 \\
& $(0.0154)$ & $(0.00172)$ \\
NP & $-3.03 e-11$ & $-1.28 \mathrm{e}-11$ \\
& $(4.24 \mathrm{e}-11)$ & $(1.29 \mathrm{e}-11)$ \\
BTMR & -0.00622 & -0.00821 \\
& $(0.163)$ & $(0.0806)$ \\
CEDR & -0.00508 & -0.00403 \\
& $(0.00655)$ & $(0.00413)$ \\
MA & 0.0312 & $-0.214^{* * *}$ \\
& $(0.0966)$ & $(0.0475)$ \\
Constant & -0.0199 & $-0.509^{* * *}$ \\
& $(0.135)$ & $(0.0664)$ \\
Observations & 1001 & 4,844 \\
\hline
\end{tabular}

Robust standard errors are in parentheses, with ${ }^{* * *}$,** and * denoting significance at $1 \%, 5 \%$ and $10 \%$, respectively. en $=10^{n}$, e.g., e- $6=10^{-6}$ and $\mathrm{e}+3=10^{3}$

Table 5 Probit results for mining industry

\begin{tabular}{lll}
\hline Variables & $\begin{array}{l}\text { Model 1 } \\
\text { EP }\end{array}$ & $\begin{array}{l}\text { Model 2 } \\
\text { CSR }\end{array}$ \\
\hline GR & -0.0429 & -0.0927 \\
& $(0.0420)$ & $(0.0581)$ \\
NP & $8.96 e-12^{* * *}$ & $6.72 \mathrm{e}-12^{* *}$ \\
& $(3.12 \mathrm{e}-12)$ & $(3.08 \mathrm{e}-12)$ \\
BTMR & $1.748^{* * *}$ & $2.140^{* * *}$ \\
& $(0.223)$ & $(0.192)$ \\
CEDR & $-0.0865^{* *}$ & $-0.102^{* * *}$ \\
& $(0.0415)$ & $(0.0349)$ \\
MA & $1.209^{* * *}$ & $1.243^{* * *}$ \\
& $(0.198)$ & $(0.144)$ \\
Constant & $-3.379^{* * *}$ & $-3.156^{* * *}$ \\
& $(0.259)$ & $(0.202)$ \\
Observations & 1246 & 1246 \\
\hline
\end{tabular}

Robust standard errors are in parentheses, with ${ }^{* * *}, * *$ and $*$ denoting significance at $1 \%, 5 \%$ and $10 \%$, respectively. en $=10^{n}$, e.g., e $-6=10^{-6}$ and $\mathrm{e}+3=10^{3}$

\section{Empirical results and discussion}

In this section, we investigate our panel data to study the effect of M\&As on environmental sustainability.

\section{Baseline results}

\section{Results of probit model}

Table 4 presents the probit model results on the effect of M\&As on environmental sustainability for the 
manufacturing industry. Table 5 presents the results for the mining industry.

From those two tables, it is observable that for both industries, M\&As have a significant impact on corporate social responsibility. Obviously, companies participating in M\&As may be more willing to devote themselves to corporate social responsibility activities, such as environmental protection, thereby improving environmental performance. After a merger or acquisition, a company may inform the public that it has becomes a larger and more efficient organization. As a result, the firm may be more likely to carry out social responsibility activities, one dimension of which may be increasing environmental performance. Thus, Hypothesis 3, suggesting that M\&As can help companies assume more corporate social responsibilities, can be accepted.

Table 5 shows that M\&As affect whether a company is a polluting company in the mining industry, which means that M\&As have a significant role in improving environmental performance in this industry, while there is no statistically significant effect in the manufacturing industry. It is, therefore, arguable that Hypothesis 1 may hold for mining but not for manufacturing. This result is mainly because in recent years, the manufacturing industry has experienced greater transformation and upgrading in China, and its pollution impact on the environment is gradually decreasing, such that M\&As play a trivial role in improving environmental performance. On the other hand, the mining industry still maintains an extensive growth mode, where pollution problems are more rigorous. The occurrence of M\&As can often better integrate the resources of mining enterprises, improve the efficiency of resource use, and thus improve their environmental performance. Therefore, M\&As have a significant impact on the environmental performance of heavily polluting industries.

Consequently, we can affirm that Hypothesis 3 is verified, while Hypothesis 1 holds for the mining industry but could be inaccurate for describing the relation between M\&As and environmental performance in the manufacturing industry. Thus, we emphasize that M\&As have a positive effect on environmental performance for heavily polluting industries.

\section{Pooled results}

The remaining panel data are applied to evaluate Hypotheses 2 and 4 in these two industries:

$$
\begin{aligned}
Y_{1, t}= & \alpha_{1}+\beta_{\mathrm{EC} 1} \mathrm{GR}_{(i, t)}+\alpha_{\mathrm{EC} 2} \mathrm{NP}_{(i, t)} \\
& +\alpha_{\mathrm{EC} 3} \mathrm{BTMR}_{(i, t)}+\alpha_{\mathrm{EC} 4} \mathrm{CEDR}_{(i, t)} \\
& +\alpha_{\mathrm{EC} 5} \mathrm{MA}_{(i, t)}+\varepsilon_{1},
\end{aligned}
$$

where $Y_{1, t}=\mathrm{EC}, i=$ manufacturing industry and mining industry and $t$ is the time period. $Y_{1, t}$ represents the environmental cost of the industry affected by the above factors in a certain period of time.

Similarly, we use a pooled model for GF, with the formula as follows:

$$
\begin{aligned}
& Y_{2, t}=\alpha_{2}+\beta_{\mathrm{GF} 1} \mathrm{GR}_{(i, t)}+\alpha_{\mathrm{GF} 2} \mathrm{NP}_{(i, t)} \\
& +\alpha_{\mathrm{GF} 3} \mathrm{BTMR}_{(i, t)}+\alpha_{\mathrm{GF} 4} \mathrm{CEDR}_{(i, t)} \\
& +\alpha_{\mathrm{GF} 5} \mathrm{MA}_{(i, t)}+\varepsilon_{2} \text {, }
\end{aligned}
$$

where $Y_{2, t}=\mathrm{GF}, i=$ manufacturing industry and mining industry and $t$ is the time period. $Y_{2, t}$ represents the green financing of the industry affected by the above factors in a certain period of time. Due to missing data related to manufacturing, there is no pooled model of GF for manufacturing.

The results of these two models are displayed in Tables 6 and 7.

This table presents the results of the impact of the control variables and MA on the environmental cost in the manufacturing industry. From this table, we can see that MA exhibits a significant impact on reducing environmental costs in the manufacturing industry. More importantly, the coefficient is $4.476 \mathrm{e}+07$, which is a positive number, indicating that MA has a positive effect on reducing environmental costs in the manufacturing industry. This result supports Hypothesis 2. For Hypothesis 4 , due to the large amount of missing data, the result may be unreliable, so we have not presented it in this paper.

Table 6 Pooled results for manufacturing industry

\begin{tabular}{lll}
\hline Variables & $\begin{array}{l}\text { Model 1 } \\
\text { EC }\end{array}$ & $\begin{array}{l}\text { Model 2 } \\
\text { RD }\end{array}$ \\
\hline GR & $-1.989 \mathrm{e}+06$ & $-101,957$ \\
& $(3.461 \mathrm{e}+06)$ & $(725,906)$ \\
$\mathrm{NP}$ & -0.00177 & 0.00256 \\
& $(0.00519)$ & $(0.00368)$ \\
BTMR & $5.687 \mathrm{e}+07$ & $4.776 \mathrm{e}+07^{* *}$ \\
& $(3.459 \mathrm{e}+07)$ & $(2.346 \mathrm{e}+07)$ \\
CEDR & 87,485 & $-499,169$ \\
& $(967,793)$ & $(864,816)$ \\
MA & $4.476 \mathrm{e}+07^{* *}$ & $5.752 \mathrm{e}+07^{* * *}$ \\
& $(1.764 \mathrm{e}+07)$ & $(1.232 \mathrm{e}+07)$ \\
Constant & $1.029 \mathrm{e}+08^{* * *}$ & $8.318 \mathrm{e}+07^{* * *}$ \\
& $(2.576 \mathrm{e}+07)$ & $(1.780 \mathrm{e}+07)$ \\
Observations & 4676 & 11,004 \\
R-squared & 0.002 & 0.002 \\
\hline
\end{tabular}

Robust standard errors are in parentheses, with ***,** and * denoting significance at $1 \%, 5 \%$ and $10 \%$, respectively. en $=10^{n}$, e.g., e $-6=10^{-6}$ and $\mathrm{e}+3=10^{3}$ 
Table 7 Pooled results for mining industry

\begin{tabular}{llll}
\hline Variables & Model 1 & Model 2 & Model 3 \\
& EC & GF & RD \\
\hline GR & $-8.234 \mathrm{e}+06$ & $-287,322$ & $1.869 \mathrm{e}+06$ \\
& $(6.624 \mathrm{e}+06)$ & $(8.542 \mathrm{e}+06)$ & $(1.970 \mathrm{e}+07)$ \\
NP & $0.00311^{* *}$ & 0.000352 & $0.104^{* * *}$ \\
& $(0.00143)$ & $(0.00185)$ & $(0.00478)$ \\
BTMR & $3.985 \mathrm{e}+08^{* * *}$ & $7.940 \mathrm{e}+07$ & $6.513 \mathrm{e}+07$ \\
& $(5.441 \mathrm{e}+07)$ & $(7.016 \mathrm{e}+07)$ & $(1.871 \mathrm{e}+08)$ \\
CEDR & $-142,000$ & $-28,506$ & $-72,554$ \\
& $(254,014)$ & $(327,558)$ & $(565,176)$ \\
MA & $6.826 \mathrm{e}+07^{*}$ & $3.452 \mathrm{e}+07$ & $2.618 \mathrm{e}+08^{*}$ \\
& $(4.018 \mathrm{e}+07)$ & $(5.181 \mathrm{e}+07)$ & $(1.371 \mathrm{e}+08)$ \\
Constant & $5.702 \mathrm{e}+06$ & $-3.248 \mathrm{e}+07$ & $-1.003 \mathrm{e}+08$ \\
& $(3.569 \mathrm{e}+07)$ & $(4.602 \mathrm{e}+07)$ & $(1.228 \mathrm{e}+08)$ \\
Observations & 1246 & 1246 & 644 \\
R-squared & 0.062 & 0.002 & 0.449 \\
\hline Robust standad & & (125) &
\end{tabular}

Robust standard errors are in parentheses, with ${ }^{* * *}, *^{*}$ and ${ }^{*}$ denoting significance at $1 \%, 5 \%$ and $10 \%$, respectively. en $=10^{n}$, e.g., $e-6=10^{-6}$ and $\mathrm{e}+3=10^{3}$

This table presents the results of the impact of the control variables and M\&As on environmental costs and green financing in the mining industry. From the table, we can see that MA exhibits a weak impact on reducing environmental costs in the mining industry. However, the coefficient is $6.826 \mathrm{e}+07$, which is a positive number, indicating that $M \& A s$ have a positive effect on reducing environmental costs in the manufacturing industry. This result weakly supports Hypothesis 2. On the other hand, M\&As have an insignificant effect on green credit financing, although the coefficient is still positive. The results reveal that M\&As among mining enterprises help reduce environmental costs but have a trivial effect on obtaining green credit financing.

Therefore, we can suggest that M\&As have a positive effect on reducing environmental costs in both industries, which may indicate that after M\&As, companies tend to have more long-term accounts payable given their larger size. Therefore, we use $R \& D$ expenditure to further investigate this issue. We argue that a large proportion of long-term accounts payable includes accounts payable for importing equipment, which may be attributable to $R \& D$ expenditure. Therefore, we explore the effect of M\&As on R\&D expenditure in model 2 in Table 6 and model 4 in Table 7 . It is clear that M\&As have a strong positive effect on $R \& D$ expenditure. This indicates that after M\&As, companies tend to invest more in $R \& D$, which can partially explain why M\&As increase the environmental cost in model 1 in both Tables 6 and 7 .

\section{Robustness check}

For the robustness purpose of our results regarding Hypotheses 1-4, we introduced both Gauss Markov Model and Logit regression model in this section. To ensure that our results are BLUE (Best Linear Unbiased Estimator), we apply the Gauss Markov Theorem based on the Gauss Markov Model. Three basic assumptions have been checked according to the Theorem [72, 73]:

1. The error terms of our regression models have a mean of zero;

2. The error terms of all our regression models are uncorrelated with the key explanatory variable;

3. The error terms of all models have a constant variance with no heteroskedasticity effect.

For checking the above assumptions, we first check the mean of error terms of all models and results are reported in Table 8 and it is clear that all error terms for our models have the mean close to zero. As a result, assumption

Table 8 Mean of error term for both manufacturing and mining industries

\begin{tabular}{lll}
\hline Model & $\begin{array}{l}\text { Mean of Error Term for } \\
\text { Manufacturing }\end{array}$ & $\begin{array}{l}\text { Mean of Error } \\
\text { Term for } \\
\text { Mining }\end{array}$ \\
\hline EP & $-3.42 e-10$ & $6.72 \mathrm{e}-09$ \\
CSR & $5.02 \mathrm{e}-11$ & $5.05 \mathrm{e}-10$ \\
EC & -0.0045 & -0.02 \\
RD & 0.001 & 0.029 \\
GF & N/A & -0.0078 \\
\hline
\end{tabular}

This table reports the mean of error terms of each model regarding Hypotheses 1-4. en $=10^{n}$, e.g., $\mathrm{e}-6=10^{-6}$ and $\mathrm{e}+3=10^{3}$

Table 9 Pearson correlation between explanatory variable with error term for both manufacturing and mining industries

\begin{tabular}{lll}
\hline Model & $\begin{array}{l}\text { Pearson Correlation for } \\
\text { Manufacturing }\end{array}$ & $\begin{array}{l}\text { Pearson } \\
\text { Correlation for } \\
\text { Mining }\end{array}$ \\
\hline EP & -0.01 & -0.06 \\
& $(0.99)$ & $(0.99)$ \\
CSR & -0.01 & -0.01 \\
& $(0.99)$ & $(0.99)$ \\
EC & 0.02 & -0.01 \\
& $(0.98)$ & $(0.99)$ \\
RD & -0.01 & 0.07 \\
& $(0.99)$ & $(0.96)$ \\
GF & N/A & -0.01 \\
& & $(0.99)$ \\
\hline
\end{tabular}

This table reports Pearson correlation between explanatory variable with error term for both manufacturing and mining industries of each model regarding Hypotheses 1-4. $P$ values are in parentheses 
Table 10 White test result for both manufacturing and mining industries

\begin{tabular}{lll}
\hline Model & White's Test for Manufacturing & $\begin{array}{l}\text { White's } \\
\text { Test for } \\
\text { Mining }\end{array}$ \\
\hline EP & 5.43 & 6.56 \\
& $(0.99)$ & $(0.99)$ \\
CSR & 14.49 & 13.28 \\
& $(0.69)$ & $(0.58)$ \\
EC & 9.59 & $61.97^{* * *}$ \\
& $(0.96)$ & $(0.01)$ \\
RD & 19.29 & 6.33 \\
& $(0.43)$ & $(0.99)$ \\
GF & NA & 7.58 \\
& & $(0.99)$ \\
\hline
\end{tabular}

This table reports the White test result for both manufacturing and mining industries of each model regarding Hypotheses 1-4 to check heteroskedasticity effect. $P$ values are in parentheses

Table 11 Newey-West robust regression result for EC model regarding mining industry

\begin{tabular}{ll}
\hline Variables & EC \\
\hline NP & $0.00311^{*}$ \\
& $(0.00182)$ \\
GR & $-8,234,302^{* * *}$ \\
& $(3,039,145)$ \\
BTMR & $3.98 \mathrm{E}+08^{* * *}$ \\
& $(6.31 \mathrm{E}+07)$ \\
CEDR & $-141,999.9^{* * *}$ \\
& $(31,240.48)$ \\
MA & $6.83 \mathrm{E}+07^{*}$ \\
& $(3.87 \mathrm{E}+07)$ \\
Constant & $5,701,648$ \\
& $(2.83 \mathrm{E}+07)$ \\
Observations & 1246
\end{tabular}

Robust standard errors are in parentheses, with $* * * * *$ and $*$ denoting significance at $1 \%, 5 \%$ and $10 \%$, respectively. en $=10^{n}$, e.g., e- $-6=10^{-6}$ and $\mathrm{e}+3=10^{3}$

1 has been verified. Then, we have employed the Pearson correlation coefficient test for the correlation between the error term with our key explanatory variable, namely, the M\&A variable. The results are presented in Table 9, where all correlation coefficients are insignificant and thus assumption 2 has been verified. Finally, we apply the White test for checking the heteroskedasticity effect [74]. The results are presented in Table 10, where all Chi-2 statistics are insignificant except the EC model for mining industry. Consequently, assumption 3 has been verified without the EC model for mining industry. Therefore, we further employ the Newey-West robust regression
Table 12 Logistic results for manufacturing industry

\begin{tabular}{lll}
\hline Variables & $\begin{array}{l}\text { Model 1 } \\
\text { EP }\end{array}$ & $\begin{array}{l}\text { Model 2 } \\
\text { CSR }\end{array}$ \\
\hline GR & -0.00788 & 0.00271 \\
& $(0.02553)$ & $(0.00269)$ \\
NP & $-4.74 \mathrm{E}-11$ & $-2.24 \mathrm{E}-11$ \\
& $(6.68 \mathrm{E}-11)$ & $(2.29 \mathrm{E}-11)$ \\
BTMR & -0.01018 & -0.01077 \\
& $(0.25951)$ & $(0.13736)$ \\
CEDR & -0.00787 & -0.00733 \\
& $(0.01045)$ & $(0.00785)$ \\
MA & 0.04993 & $-0.35971^{* * *}$ \\
& $(0.15428)$ & $(0.07939)$ \\
Constant & -0.03260 & $-0.82177^{* * *}$ \\
& $(0.21546)$ & $(0.11201)$ \\
Observations & 1001 & 4844 \\
\hline
\end{tabular}

Robust standard errors are in parentheses, with ${ }^{* * *}, * *$ and ${ }^{*}$ denoting significance at $1 \%, 5 \%$ and $10 \%$, respectively. en $=10^{n}$, e.g., e $-6=10^{-6}$ and $\mathrm{e}+3=10^{3}$

Table 13 Logistic results for mining industry

\begin{tabular}{lll}
\hline Variables & $\begin{array}{l}\text { Model 1 } \\
\text { EP }\end{array}$ & $\begin{array}{l}\text { Model 2 } \\
\text { CSR }\end{array}$ \\
\hline GR & $-0.07716^{* * *}$ & -0.16813 \\
& $(0.07816)$ & $(0.11266)$ \\
NP & $1.65 \mathrm{E}-11^{* * *}$ & $1.22 \mathrm{E}-11^{* *}$ \\
& $(5.40 \mathrm{E}-12)$ & $(5.24 \mathrm{E}-12)$ \\
BTMR & $3.27223^{*}$ & $3.71164^{* * *}$ \\
& $(0.43255)$ & $(0.35165)$ \\
CEDR & -0.15195 & $-0.16631^{* * *}$ \\
& $(0.08170)$ & $(0.06227)$ \\
MA & $2.60662^{* * *}$ & $2.37341^{* * *}$ \\
& $(0.48105)$ & $(0.30069)$ \\
Constant & $-6.54521^{* * *}$ & $-5.68728^{* * *}$ \\
& $(0.58163)$ & $(0.39826)$ \\
Observations & 1246 & 1246
\end{tabular}

Robust standard errors are in parentheses, with ***,** and * denoting significance at $1 \%, 5 \%$ and $10 \%$, respectively. en $=10^{n}$, e.g., $\mathrm{e}-6=10^{-6}$ and $\mathrm{e}+3=10^{3}$

method to adjust the EC model which indicates heteroskedasticity. The results are presented in Table 11, which are almost identical compared with the results in Table 7. Therefore, it is arguable that our regression estimations are BLUE and our results are robust.

Furthermore, we use an alternative method for the probit regression model, which is the logit model for both manufacturing and mining industries. Tables 12 and 13 report the results of logit model for manufacturing and 
mining industry, respectively. Compare the results with our probit model in Tables 4 and 5, results are quite similar for both models.

Regarding the endogeneity problem, this problem arises when the explanatory variable is correlated with the error term, which is often referred as the "fixed effect" in panel data analysis. In this case, endogeneity becomes a concern, since the explanatory variable is correlated with the error term $[75,76]$. In our model, we use pooled data model rather than the fixed effect model. More importantly, we have demonstrated that our key explanatory variable is uncorrelated with the error term for all models (see Table 9). As a result, the endogeneity problem may not be relevant to our model. It is thereby believable that our results are robust.

\section{Mediating effect of corporate governance}

The above conclusions provide preliminary results for Hypotheses 1 to 4 . In this section, the mediating variable CG is incorporated to further analyze the influence mechanism of M\&As on all dependent variables. We again analyze the same two industries. For the mediating effect investigation, we adopt the three-step mediation regression method proposed by Baron and Kenny [77]. Those above results can be aligned with the first step in Baron and Kenny [77]. Then, we undertake the next two steps as shown from Eqs. (6) to (11).

First, we regress CG on EP, CSR, EC, and GF to unpack the relation between the mediator and dependent variables. Then, we regress CG with M\&A and control variables to reveal the relation between the mediator and explanatory variables. If both regressions deliver significant results, then it is arguable that corporate governance can serve as a mediator connecting M\&As and environmental sustainability. We further reveal that M\&As have a positive effect on environmental sustainability, which may be due to improved corporate governance after reorganization.

The model can be specified as follows:

$$
\begin{aligned}
& Y_{3, t}=\alpha_{3}+\beta_{\mathrm{EP} 1} \mathrm{CG}_{(i, t)}+\varepsilon_{3}, \\
& Y_{4, t}=\alpha_{4}+\beta_{\mathrm{CSR}_{1} \mathrm{CG}_{(i, t)}+\varepsilon_{4},} \\
& Y_{5, t}=\alpha_{5}+\beta_{\mathrm{EC} 1} \mathrm{CG}_{(i, t)}+\varepsilon_{5}, \\
& Y_{6, t}=\alpha_{6}+\beta_{\mathrm{GF} 1} \mathrm{CG}_{(i, t)}+\varepsilon_{6},
\end{aligned}
$$

Table 14 Mediating effect of corporate governance on the manufacturing industry

\begin{tabular}{llll}
\hline Variables & $\begin{array}{l}\text { Model 1 } \\
\text { EP }\end{array}$ & $\begin{array}{l}\text { Model 2 } \\
\text { CSR }\end{array}$ & $\begin{array}{l}\text { Model 3 } \\
\text { EC }\end{array}$ \\
\hline CG & $0.00486^{*}$ & 0.000723 & $1.870 \mathrm{e}+07^{* * *}$ \\
& $(0.00258)$ & $(0.00179)$ & $(6.893 \mathrm{e}+06)$ \\
Constant & $0.421^{* * *}$ & $0.855^{* * *}$ & $1.651 \mathrm{e}+08^{* *}$ \\
& $(0.0291)$ & $(0.0201)$ & $(8.231 \mathrm{e}+07)$ \\
Observations & 1806 & 1806 & 1017 \\
R-squared & 0.002 & 0.000 & 0.007 \\
\hline
\end{tabular}

Robust standard errors are in parentheses, with ***,** and * denoting significance at $1 \%, 5 \%$ and $10 \%$, respectively. en $=10^{n}$, e.g., e $-6=10^{-6}$ and $\mathrm{e}+3=10^{3}$

$$
\begin{aligned}
Y_{7, t}= & \alpha_{7}+\beta_{\mathrm{MA} 2} \mathrm{MA}_{(i, t)}+\beta_{\mathrm{GR} 2} \mathrm{GR}_{(i, t)} \\
& +\alpha_{\mathrm{NP} 2} \mathrm{NP}_{(i, t)}+\alpha_{\mathrm{BTRM}_{2} \mathrm{BTMR}_{(i, t)}} \\
& +\alpha_{\mathrm{ECER2} 2} \mathrm{CEDR}_{(i, t)}+\varepsilon_{7}, \\
Y_{8, t}= & \alpha_{8}+\beta_{\mathrm{EVAR}_{2} \operatorname{EVAR}_{(i, t)}+\beta_{\mathrm{GR} 2} \mathrm{GR}_{(i, t)}} \\
& +\alpha_{\mathrm{NP} 2 \mathrm{NP}_{(i, t)}}+\alpha_{\mathrm{BTRM} 2} \mathrm{BTMR}_{(i, t)} \\
& +\alpha_{\mathrm{ECEDR} 2} \mathrm{CEDR}_{(i, t)}+\varepsilon_{8},
\end{aligned}
$$

where $Y_{3, t}=\mathrm{EP}$, which denotes the environmental performance of the manufacturing industry and mining industry over the sample period.

Specifically, $Y_{4, t}=$ CSR, which indicates the corporate social responsibility of the manufacturing industry and mining industry over the sample period. $Y_{5, t}=\mathrm{EC}$, which denotes the environmental cost of the manufacturing industry and mining industry over the sample period. $Y_{6, t}=\mathrm{GF}$, which denotes the green financing of the manufacturing industry and mining industry over the sample period. $Y_{7, t}=\mathrm{CG}_{1}$ and $Y_{8, t}=\mathrm{CG}_{2}$, which mean that the corporate governance of the manufacturing industry and mining industry over the sample period was affected. $i$ is the individual listed company inside either the manufacturing or the mining industry, and $t$ is time. $Y_{3, t}$ represents the environmental performance affected by mediator CG over the sample period. $Y_{4, t}$ represents corporate social responsibility affected by mediator CG over the sample period. $Y_{5, t}$ represents the environmental cost affected by mediator CG over the sample period. $Y_{6, t}$ represents green credit financing affected by mediator CG over the sample period. $Y_{7, t}$ represents the mediator CG affected by M\&As and other factors over the sample period. $Y_{8, t}$ represents the mediator CG affected by EVAR and other factors over the sample period. Due to missing data related to manufacturing, there is no pooled model for GF in manufacturing. 
Table 15 Regression results for manufacturing industry

\begin{tabular}{lll}
\hline Variables & $\begin{array}{l}\text { Model 1 } \\
\text { CG }\end{array}$ & $\begin{array}{l}\text { Model 2 } \\
\text { CG }\end{array}$ \\
\hline MA & 0.0430 & \\
& $(0.342)$ & \\
GR & -0.0261 & -0.0716 \\
& $(0.0535)$ & $(0.0810)$ \\
NP & $-2.20 \mathrm{e}-10$ & $-6.09 \mathrm{e}-10^{*}$ \\
& $(1.73 \mathrm{e}-10)$ & $(3.35 \mathrm{e}-10)$ \\
BTMR & 0.102 & -0.337 \\
& $(0.600)$ & $(1.028)$ \\
CEDR & -0.000565 & 0.0282 \\
& $(0.0192)$ & $(0.0643)$ \\
EVAR & & $0.0701^{* * *}$ \\
& & $(0.0188)$ \\
Constant & $10.31^{* * *}$ & $11.77^{* * *}$ \\
& $(0.484)$ & $(0.703)$ \\
Observations & 860 & 270 \\
R-squared & 0.002 & 0.065 \\
\hline
\end{tabular}

Robust standard errors are in parentheses, with ***,** and * denoting significance at $1 \%, 5 \%$ and $10 \%$, respectively. en $=10^{n}$, e.g., $e-6=10^{-6}$ and $\mathrm{e}+3=10^{3}$.

From Table 14, CG in the manufacturing industry is statistically significant in model 3 and weakly significant in model 1 , while it is not significant in model 2 . These results suggest that the intermediary variable has a positive effect on the reduction of environmental costs and, to a certain extent, on the improvement of environmental performance but that it has no effect on corporate social responsibility. Due to missing data for manufacturing, we have not presented GF results for this industry. In addition, it is clear from Table 15 that M\&As have no significant effect on the intermediary variable CG, while EVAR is significantly related to the intermediary variable.

In summary, M\&As may have a trivial effect on EP, CSR or EC through the intermediary variable CG, while EVAR has an impact on EP and EC through CG in the manufacturing industry. Therefore, we may argue that after M\&As, companies can enhance environmental sustainability via better corporate governance if their economic value-added rate rises considerably.

According to Table 16, CG in the mining industry is statistically significant in all models. This result suggests that the intermediary variable CG has a positive effect on the reduction of environmental costs, the improvement of environmental performance, corporate social responsibility, and green financing in the mining industry.

As shown in Table 17, M\&As have a significant effect on the intermediary variable CG, and its coefficient is
Table 16 Mediating effect of corporate governance on the mining industry

\begin{tabular}{lllll}
\hline Variables & $\begin{array}{l}\text { Model 1 } \\
\text { EP }\end{array}$ & $\begin{array}{l}\text { Model 2 } \\
\text { CSR }\end{array}$ & $\begin{array}{l}\text { Model 3 } \\
\text { EC }\end{array}$ & $\begin{array}{l}\text { Model 4 } \\
\text { GF }\end{array}$ \\
\hline CG & $0.0511^{* * *}$ & $0.0668^{* * *}$ & $3.777 e+07^{* * *}$ & $2.803 e+07^{* * *}$ \\
& $(0.00152)$ & $(0.00198)$ & $(5.150 e+06)$ & $(6.525 e+06)$ \\
Constant & $0.0221^{* * *}$ & $0.0749^{* * *}$ & $2.032 \mathrm{e}+08^{* * *}$ & $-6.967 \mathrm{e}+06$ \\
& $(0.00600)$ & $(0.00784)$ & $(2.039 \mathrm{e}+07)$ & $(2.584 \mathrm{e}+07)$ \\
Observations & 1250 & 1248 & 1248 & 1248 \\
R-squared & 0.476 & 0.477 & 0.041 & 0.015 \\
\hline
\end{tabular}

Robust standard errors are in parentheses, with ${ }^{* * *}, * *$ and ${ }^{*}$ denoting significance at $1 \%, 5 \%$ and $10 \%$, respectively. en $=10^{n}$, e.g., e $-6=10^{-6}$ and $\mathrm{e}+3=10^{3}$

positive, at 1.468. EVAR is not significant in relation to the intermediary variable.

According to Tables 16 and 17, M\&As have a significant effect on EP, CSR, EC and GF through the intermediary variable $C G$, while EVAR has no impact on these variables through the intermediary variable $C G$ in the mining industry. This conclusion is similar to the previous conclusions, so we believe that the mediating variable CG plays an important role in this relationship. Through improved supervision by the board of directors, M\&A activities have a positive effect on all four outcomes.

Through the result, it is arguable that corporate governance plays an important role in environment sustainability. Our result thus complements the agency theory,

Table 17 Regression results for mining industry

\begin{tabular}{lll}
\hline Variables & $\begin{array}{l}\text { Model 1 } \\
\text { CG }\end{array}$ & $\begin{array}{l}\text { Model 2 } \\
\text { CG }\end{array}$ \\
\hline MA & $1.468^{* * *}$ & \\
& $(0.209)$ & \\
GR & -0.0260 & -0.0127 \\
& $(0.0344)$ & $(0.0350)$ \\
NP & $0^{* * *}$ & $0^{* *}$ \\
& $(0)$ & $(0)$ \\
BTMR & $2.359^{* * *}$ & $2.879^{* * *}$ \\
& $(0.282)$ & $(0.278)$ \\
CEDR & -0.00117 & -0.000986 \\
& $(0.00132)$ & $(0.00134)$ \\
EVAR & & -0.00800 \\
& & $(0.0117)$ \\
Constant & $-0.819^{* * *}$ & -0.262 \\
& $(0.185)$ & $(0.172)$ \\
Observations & 1246 & 1246 \\
R-squared & 0.130 & 0.095 \\
\hline
\end{tabular}

Robust standard errors are in parentheses, with ${ }^{* * *}, * *$ and * denoting significance at $1 \%, 5 \%$ and $10 \%$, respectively 
since agency theory focuses on economic interest harmonization through corporate governance. We further demonstrate that corporate governance can also be effective on the social benefits harmonization, such as protecting environment sustainability.

In summary, corporate governance generally has a crucial mediating effect on environmental sustainability in both industries under our investigation. Specifically, manufacturing companies are more sensitive to the economic value added rate. Higher value added can lead to better corporate governance and further affect environmental sustainability. On the other hand, mining companies are less sensitive to the economic value added rate. In contrast, they are more sensitive to M\&A deals. Therefore, we can infer that the resource efficiency optimization through M\&A deals is more substantial for mining companies.

\section{Conclusions and research implications}

This paper investigates the effect of M\&As on environmental sustainability for heavily polluting industries, mainly focusing on the manufacturing and mining industries. We measure environmental sustainability in terms of four outcomes: environmental performance, environmental cost, corporate social responsibilities and green finance. We find that M\&As can improve environmental performance for mining companies but not for manufacturing companies. We further reveal that M\&As can enhance corporate social responsibility among companies in both industries. We then illustrate that the effect of M\&As on green finance is trivial. Finally, we find that M\&As have a positive effect on environmental costs. We further explore this issue by analyzing the effect of M\&As on $R \& D$ expenditure, and we demonstrate that M\&As positively impact $R \& D$ expenditure, which could partially impact the environmental cost.

Next, we scrutinize the mechanism, whereby M\&As affect environmental sustainability by arguing that the positive effect could be attributed to better corporate governance. We thus test for a mediating effect of corporate governance. Of the two industries, the mediating effect is more noticeable in the mining industry, where all four variables substantially respond to fluctuations in corporate governance and M\&As have a significant effect on corporate governance. On the other hand, the mediating effect of corporate governance appears only in relation to corporate social responsibility in the manufacturing industry. Corporate governance plays a vital role in enhancing the environmental sustainability of mining companies in China. It is plausible that M\&As trigger company reorganizations and thus optimize the firm structure, resulting in better corporate governance that can provoke company management changes in several aspects, such as sustainable environmental development. These results offer the remarkable insight that mining companies in China may require better corporate boards to make the companies more environmentally friendly. Moreover, we also argue that firms enhance the environment sustainability is not only for survival but also for the environment protection. It is because all sampled firms are listed companies with huge net profits and high capacity growth rate (see Table 1 for the averaged values). As a result, for those firms, they intend to build reputations though fulfill higher social responsibilities, such as protecting environment.

Our study also has enormous policy implications, in that it reflects that M\&As can improve environmental sustainability in several respects. M\&A activities in mining companies have a more significant and positive impact on environmental sustainability through the channel of corporate governance. As a result, the government can promote corporate governance changes in mining companies through M\&A-induced board reorganizations, which can lead to sustainable environmental development. In particular, for manufacturing and mining companies, we suggest they put heavier weight on research and development, since advanced technology can help them on strengthening environment sustainability. On the other hand, the government can provide larger amount of green finance and credits for those companies that devote resources in strengthening environment sustainability.

\section{Abbreviations}

BTMR: Book-to-market ratio; CEDR: Capital expenditure and depreciation and amortization ratio; CG: Corporate governance; CSR: Corporate social responsibility; EC: Environmental cost; EP: Environmental performance; EVAR: Economic value added rate; GF: Green finance; GR: Growth rate; M\&A: Mergers and acquisition; R\&D: Research \& Development.

\section{Acknowledgements}

This work was supported by the Academy of Longyuan Construction Financial Research, Ningbo University. This work was also supported by the Research Academy of Belt and Road, Ningbo University.

\section{Authors' contributions}

The research was designed and performed by SD and TC. The data were collected by ZY. Data analysis was performed by DZ and ZY. Finally, the paper was written by SD and DZ. All authors read and approved the final manuscript.

\section{Funding}

Not applicable.

Availability of data and materials

Not applicable.

\section{Declarations}

Ethics approval and consent to participate Not applicable. 


\section{Consent for publication}

Written informed consent for publication was obtained from all participants.

\section{Competing interests}

The authors declare no conflicts of interest. The sponsors had no role in the design of the study, in the collection, analyses, or interpretation of data, in the writing of the manuscript, or in the decision to publish the results.

\section{Author details}

${ }^{1}$ The School of Business, Ningbo University, Ningbo, China. ${ }^{2}$ Ningbo Open University, Ningbo, China. ${ }^{3}$ School of Economics and Management, Northeast Agricultural University, Harbin, China. ${ }^{4}$ School of Computer Science, University of Nottingham Ningbo China, Ningbo, China.

Received: 12 April 2021 Accepted: 26 October 2021

Published online: 05 November 2021

\section{References}

1. Elkington J (1998) Accounting for the trip bottom line. Meas Bus Excel 2:18-22. https://doi.org/10.1108/eb025539

2. Janet H, Gary P (2017) The triple bottom line and sustainable economic development theory and practice. Econ Dev Q 31:25-36. https://doi.org/ $10.1177 / 0891242416674808$

3. Schippe K, Thompson R (2006) Evidence on the capitalized value of merger activity for acquiring firms. J Financ Econ 11:85-119. https://doi. org/10.1016/0304-405X(83)90006-5

4. John E (1997) Cannibals with forks: the triple bottom line of 21st century business. Capstone, Oxford, pp 231-240

5. Koondhar MA, Tan Z, Alam GM, Khan ZA, Wang L, Kong R (2021) Bioenergy consumption, carbon emissions, and agricultural bioeconomic growth: a systematic approach to carbon neutrality in China. J Environ Manage 296:113242. https://doi.org/10.1016/j.jenvman.2021.113242

6. Liu X, Wahab S, Hussain M, Sun Y, Kirikkaleli D (2021) China carbon neutrality target: revisiting FDI-trade-innovation nexus with carbon emissions. J Environ Manage 294:113043. https://doi.org/10.1016/j.jenvman. 2021.113043

7. Goerner SJ, Lietaer B, Ulanowicz RE (2009) Quantifying economic sustainability: implications for free-enterprise theory, policy and practice. Ecol Econ 69:76-81. https://doi.org/10.1016/j.ecolecon.2009.07.018

8. Shrivastava P (1986) Post-merger integration. J Bus Strateg 7:65-76

9. Sebastian K, Han Z (2010) Holistic analysis instead of in-depth research: a summary of corporate mergers and acquisitions theory based on holistic analysis research methods. East China Econ Manage 24:138-144

10. Drobetz W, Paul PM (2020) Corporate governance convergence in the European M\&A market. Financ Res Lett 32:101091. https://doi.org/10. 1016/j.frl.2019.01.003

11. Yuan L, Xu H (2012) Research on the construction of comprehensive evaluation index system for the success or failure of M\&A of listed companies in China. In: Proceedings of the 2012 symposium on management innovation. Intelligent Technology and Econ Development

12. Daily CM, Dalton DR, Cannella JAA (2003) Corporate governance: decades of dialogue and data. Acad Manage Rev 28:371-382. https://doi.org/10. 5465/AMR.2003.10196703

13. Jensen MC, Meckling WH (1976) Theory of the firm: managerial behavior, agency cost and ownership structure. J Financ Econ 3:305-360

14. Xu S, Bao H (2020) Research on energy and environmental performance evaluation of China Coal based on five-dimensional balanced scorecard. Farm Econ Manage 6:54-56

15. You J, Zhang Y (2020) The impact of corporate social responsibility and environmental performance on environmental performance information disclosure. China Coal 46:18-23

16. Ke S, Ai L (2020) Analysis on environmental cost accounting and control of polluting enterprises, pp 1-4. https://doi.org/10.16144/j.cnki.issn10028072.20200720.001

17. LiW, Xiao H (2009) A five-dimensional model for the construction of corporate social responsibility index system of stakeholder responsibility content function organization hierarchy function attribute. WTO Econ Guide 3:69-71
18. Zhang Z, Liang Z, Yin K (2012) Research on corporate social responsibility from the perspective of stakeholders. China Soft Sci 2:139-147

19. Tang X (2020) Social responsibility, M\&A premium and IPO Audit Fees. Financ Account News 19:49-52

20. Deng X, Kang JK, Low BS (2012) Corporate social responsibility and stakeholder value maximization: evidence from mergers. J Financ Econ. https://doi.org/10.2139/ssrn.2067416

21. Peng Y, Song S, Xu Y, Dong Y (2018) Innovate or merge? The role of corporate social responsibility in the relationship between $R \& D$ and mergers and acquisitions. https://doi.org/10.2139/ssrn.3137932

22. Peng Y, Song S, Skowronski K, Dong Y (2020) Social responsibility and operational risks in merger and acquisition decisions. Social Science Electronic Publishing, New York. https://doi.org/10.2139/ssrn.3525305

23. Ding J, Hu R (2020) Regional environmental regulation and the effectiveness of green credit policy: from the perspective of credit financing of heavy polluting enterprises. Soft Sci 1-10

24 Luo S, Yu S, Zhou G (2021) Does green credit improve the core competence of commercial banks? Based on quasi-natural experiments in China. Energy Econ. https://doi.org/10.1016/j.eneco.2021.105335

25. Kalloch A, Bachman B (2011) Green banking. Missouri Univ Sci Technol

26 Amir MK (2021) Banker Attitudes and perception towards green banking: an empirical study on conventional banks in Bangladesh. Int J Financ Bank Stud 10:47-56. https://doi.org/10.20525/ijfbs.v10i2.1163

27. Glaister KW, Ahammad MF (2010) Motives for cross border mergers and acquisitions: perspective of UK firms. Social Science Electronic Publishing, New York, pp 1-32. https://doi.org/10.2139/ssrn.1549812

28. Yoo K, Lee Y, Heo E (2013) Economic effects by merger and acquisition types in the renewable energy sector: an event study approach. Renew Sustain Energy Rev 26:694-701. https://doi.org/10.1016/j.rser.2013.06.002

29. Yuan X, Dai J (2015) Research on M \& A performance of resource-based enterprises: a case study of Yanzhou Coal Company's M\&A of Haosheng Coal Company. Financ Account Bull 10:8-10+4

30. Kim I, Pantzalis C, Zhang Z (2021) Multinationality and the value of green innovation. J Corp Financ 69:101996. https://doi.org/10.1016/j.jcorpfin. 2021.101996

31. Stefano C, Giuseppe G, Viktoriia P (2021) The role of sustainability performance after merger and acquisition deals in short and long-term. J Clean Prod 314:127982. https://doi.org/10.1016/j.jclepro.2021.127982

32. Ahiabo FS, James GA, Kwabi FO, Siems MM (2018) Shareholder protection, stock markets and cross-border mergers. Econ Lett 171:54-57. https://doi.org/10.1016/j.econlet.2018.07.013

33. Dandapani K, Hibbert AM, Lawrence ER (2020) The Shareholder's response to a firm's first international acquisition. J Bank Financ 118:105852. https://doi.org/10.1016/j.jbankfin.2020.105852

34. Huang F, Wang X, Tian L, Sun L (2020) Venture capital, synergy and M\&A performance of listed companies. Nankai Manage Rev 23:96-106+165

35. Zhang Z, Lyles MA, Wu C (2020) The stock market performance of exploration-oriented and exploitation-oriented cross-border mergers and acquisitions: evidence from emerging market enterprises. Int Bus Rev. https://doi.org/10.1016/j.ibusrev.2020.101707

36. Hu Y (2019) M\&A analysis of environmental protection industry: a case study of Yingfeng environment's M\&A of Zoomlion Environment. Commer Econ 06:119-120+128

37. Yu H, Wang Q (2020) Construction of environmental performance evaluation index system of petroleum enterprises. Times Econ Trade 27:16-17

38. Zhou S, Wen H (2013) Research on M\&A performance evaluation system based on industry evolution and M\&A motivation. Account Res 10:75-82+97

39. Tian Z, Bao J (2010) Valuation model of strategic M\&A: a target enterprises based on environmental cost. Friends Account 04:84-86

40. Xie D, Wang P (2013) Strategic control of environmental cost of Chinese enterprises under the mode of ecological econ development. Account Res 03:88-94+96

41. Horst R, Michael R, Frank S (2009) The choice of market entry mode: greenfield investment, M\&A and joint venture. Inte Rev Econ Financ 18:3-10. https://doi.org/10.1016/j.iref.2008.02.006

42. Pirmana V, Alisjahbana AS, Yusuf AA, Hoekstra R, Tukker A (2021) Environmental costs assessment for improved environmental-economic account for Indonesia. J Cleaner Prod 280:124521

43. Cai X, Zhu B, Zhang H, Li L, Xie M (2020) Can direct environmental regulation promote green technology innovation in heavily polluting 
industries? Evidence from Chinese listed companies. Sci Total Environ 746:140810

44. Zhang J, Wang Y, Zhang H, Zhang Z (2016) Literature review on corporate social responsibility and corporate mergers and acquisitions. J Shijiazhuang Univ Econ 5:97-100

45. Basile R (2004) Acquisition versus greenfield investment: the location of foreign manufacturers in Italy. Reg Sci Urban Econ 34:3-25

46. Gao H, Hu C (2019) The impact of green M\&A on the performance of listed companies in China's high energy consuming industries. J East China Normal Univ (Philo and Soc Sci Edition): 6

47. Waddock SA, Graves SB (1997) The corporate social performance-financial performance link. Strategic Manage J 18:303-319

48. Standaert M (2009) China's "green credit" policies encourage banks to end financing for repeat polluters. Int Environ Rep 32:749

49. David DW, Zeng P, Lan H (2018) Co-patent, financing constraints, and innovation in SMEs: an empirical analysis using market value panel data of listed firms. J Eng Technol Manage 48:15-27

50. Simin A, Li B, Song D, Chen X (2020) Green credit financing versus trade credit financing in a supply chain with carbon emission limits. Eur J Oper Res 292:125-142. https://doi.org/10.1016/j.ejor.2020.10.025

51. Bai Y (2016) Financing a green future: an examination of China's banking sector for green finance

52. Yu L, Zhao D, Xue Z, Gao Y (2020) Research on the use of digital finance and the adoption of green control techniques by family farms in China. Technol in Soc 62:101323. https://doi.org/10.1016/j.techsoc.2020.101323

53. Xue J, Zhu D (2021) Can green credit policy improve debt financing of listed companies. Econ J 01:1-14

54. Scholtens B (2006) Finance as a driver of corporate social responsibility. J Bus Ethics 68:19-33

55. Xu L, Zhang S, Li T, Wu S (2020) Relationship between Green Finance and Industrial Structure in Central China. J West Anhui Univ 36:72-78

56. Kenneth H, Eva L (1997) Dividend policy, corporate financing, and mergers and acquisitions in Finland: a survey. Lta 4:419-453

57. Yuan L, Xu H (2012) Research on the construction of comprehensive evaluation index system for the success or failure of M\&A of listed companies in China. In: Proceedings of the 2012 symposium on management innovation. Intelligent Technol and Econ Dev

58. Guo B (2013) M\&A, industrial transformation and sustainable development-based on the analysis of sustainable development ability of China's listed coal companies. Product Res 02:57-159+175

59 Smith A (1776) An inquiry into the nature and causes of the wealth of nations. Blackwell Publishers, Oxford, pp 226-232

60. Lin Y, Zeng Y (2019) Literature review on M\&A between enterprises. China Bus Theory 19:137-140

61. Shi J, Xu W (2008) Comparison of M\&A: a theory and performance evaluation method. Mod Enterp 12:23-26

62. Klaus G, Dennis C, Mueller B, Burcin Y, Christine Z (2003) The effect of merger: an international comparison. Int J Ind Organ 21:625-653. https:// doi.org/10.1016/S0167-7187(02)00107-8

63. Li N, Yan X, Liu T (2012) Summary of cross border M \& A: a theory of enterprises. Mall Mod 20:6-7
64 Cantwell J, Barnard H (2008) Do firms from emerging markets have to invest abroad? Outward FDI and the Competitiveness Of Firms. In: Savant KP (ed) The rise of transnational corporations from emerging markets: threat or opportunity? Edward Elgar Publishing, Willinston, pp 114-136

65 Markusen JR (1998) Multinational enterprises and the theories of trade and location. In: Braunerhjelm P, Ekholm K (eds) The geography of multinational firms. Academic Publishers, Boston, pp 10-14

66. Song Y, Huang W (2018) Analysis of green M \& A performance of manufacturing enterprises based on catastrophe progression method. Financ Account Mon 12:41-47

67. Ponorica AG, Popa AF, Stanila GO (2013) Corporate governance through environment protection conditions applicable for Aeroflot Company. In: International conference on competitiveness of agro-food and environmental economy proceedings. The Bucharest Univ of Econ Stud 2:136-145

68. Jensen MC (1993) The modern industrial revolution, exit, and the failure of internal control systems. J Financ 48:831-880. https://doi.org/10. 1111/j.1540-6261.1993.tb04022.x

69. Vafeas N (2000) Board structure and the informativeness of earnings. J Account Public Policy 19:139-160. https://doi.org/10.1016/S02784254(00)00006-5

70 Wooldridge JM (2015) Introductory econometrics: a modern approach. Nelson Education, Scarborough, pp 331-359

71. Zhang N, Zuo L, Chen T, Zhang L, Dong H (2020) An empirical analysis on the construction of smart water conservancy and the willingness of rural multi-agent participation in arid areas based on probit model. Xinjiang Agric Sci 12:2340-2350

72. Zyskind G, Martin FB (1969) On best linear estimation and general GaussMarkov theorem in linear models with arbitrary nonnegative covariance structure. SIAM J Appl Math 17:1190-1202. https://doi.org/10.2307/20991 99

73. Shaffer JP (1991) The Gauss—Markov theorem and random regressors. Am Stat 45:269-273. https://doi.org/10.1080/00031305.1991.10475819

74. White HA (1980) Heteroskedasticity-consistent covariance matrix estimator and a direct test for heteroscedasticity. J Econ 48:817-838. https://doi. org/10.1016/0304-4076(85)90087-9

75. Attfield CL (1985) Homogeneity and endogeneity in systems of demand equations. J Econ 27:197-209

76. Semykina A, Wooldridge JM (2010) Estimating panel data models in the presence of endogeneity and selection. J Econ 157:375-380. https://doi. org/10.1016/j.jeconom.2010.03.039

77. Baron RM, Kenny DA (1986) The moderator-mediator variable distinction in social psychological research — conceptual, strategic, and statistical considerations. J Pers Soc Psychol 51:1173-1182. https://doi.org/10. 1037//0022-3514.51.6.1173

\section{Publisher's Note}

Springer Nature remains neutral with regard to jurisdictional claims in published maps and institutional affiliations.
Ready to submit your research? Choose BMC and benefit from:

- fast, convenient online submission

- thorough peer review by experienced researchers in your field

- rapid publication on acceptance

- support for research data, including large and complex data types

- gold Open Access which fosters wider collaboration and increased citations

- maximum visibility for your research: over $100 \mathrm{M}$ website views per year

At BMC, research is always in progress.

Learn more biomedcentral.com/submissions 